\title{
Model of adoption of Information and Communication Technologies of the Universities case of study Technical University of Cotopaxi Latacunga -Ecuador
}

\author{
$-8 \$ 1 \square \& \$ 5 / 26 \square \&+\$ 1 \& 86, * \square \&+, 6 \$ *^{1,2}$ \\ ${ }^{1}$ Universidad Nacional Mayor San Marcos - Lima, PERU \\ ${ }^{2}$ Universidad Técnica de Cotopaxi - Cotopaxi, ECUADOR \\ juan.chancusig@utc.edu.ec \\ JAVIER CRUZADO GAMBOA, 3,1 \\ ${ }^{3}$ Universidad Autónoma de Perú - Lima, PERU \\ ${ }^{1}$ Universidad Nacional Mayor San Marcos - Lima, PERU \\ Jgamboa65@hotmail.com
}

\begin{abstract}
This investigation is part of a development model to adopt the information and Communication Technologies (ICT) to the teaching-learning process at the Technical University of Cotopaxi. Specifically, to improve the higher education, as a result of the steady advances in the field of digital knowledge and educational technology, for that reason, the Institutions must improve their academic organization and education processes. Through the use of technologies, educational institutions try to integrate information and innovation. In this context and reviewing the problem case through the application of the ICT new Acceptance Model, the student's teaching-learning process will improve. The investigation showed the expected results with the creation of the latest ICT adoption model. Using collaborative tools within a collaborative learning environment (CLE) to elaborate constructs Cronbach's alpha, variance, and correlations and the statistical software were used as the Minitab validated the hypotheses.
\end{abstract}

Key Words: ICT, collaborative learning, teaching-learning, web 2.0 y web 3.0, TAM model, quantitative, educational model.

Received: September 6, 2019. Revised: March 1, 2020. Accepted: March 8, 2020. Published: March 16, 2020.

\section{Introduction}

In the era of the economics of knowledge management, the application of Information and Communication Technologies (ICT) are essential factors for the proper functioning of universities and new educational models. It requires an increasing level of collaboration and participation among students and the rest of those involved in the university - teachers, departmental heads, authorities.

The Internet and networks are the backbones of modern communications, transforming our world into ubiquitous connectivity. That is, at any time and any place, access is always available for the digital network and digital services. The evolution and revolution in Information and Communication Technologies (ICT), which recently led to notable economic and social changes. It will only increase the pace as we apply management interventions and controls for better acceptance and assimilation of ICT [1]. Education at all levels, and especially at the university level, is structured by the constant advances in the field of digital communications and educational technology. So institutions must review their administrative, academic, and research organization [2]. One of the most significant uncertainties facing higher education today is the need to prepare students and teachers for a knowledge society. That must adapt to change for the speed at which new knowledge generated.

Educational institutions, throughout their history, have used different technological resources to support their activities [3]. In the case of Ecuador, the use of ICT in education has widely developed in recent years, with emphasis on changes supported by the entry of new technologies into teaching and learning processes. It leads to the 
possibility that education reaches a more significant number of students, also allowing generating a higher generation of knowledge.

The objective of this sense is promoting and encouraging skill development, languages, spaces, and times that are emerging in the field of technology. Through dynamic forms of learning that positively affect the student's processes of education [4]. TAM's popularity can be seen in the number of studies that apply, expand, and evaluate the framework to examine the factors that affect the acceptance of technology by users in the literature on educational technology. This research project seeks to expose and establish which variables influence the adoption and use of Support Systems for Work and Collaborative Learning by users, and especially by university teachers. Therefore, we propose to develop a new model that predicts the probability that new technology will accept within a group of individuals or organizations of higher education institutions. What it looks for is to optimize the sense of the utility of the variables or factors or constructors of academic articles found by systematic review. And then create new variables based on our empirical study what determines that a university, through its teachers, decides to accept the use of Support Systems for Work and Collaborative Learning. And therefore must investigate and validate the appropriate factors, examining what level of perception they have of the usefulness and ease of use of this type of innovative technology. The new model of acceptance of technology developed in our research, applied to the Collaborative Learning Environment (CLE) systems, in this Ecuadorian university, has been carried out an investigation based on the observation of perception from the preparation of a questionnaire. That sent to a sample of teachers at the Technical University of Cotopaxi, used for the empirical analysis with a Structural Equation Model (SEM) based on the Partial Least Squares (PLS).

As an added value to doctoral research, empirical data is presented on the adoption and use of Collaborative Learning Environment (CLE) systems in university professors at the Technical University of Cotopaxi in Ecuador. There are also no equivalent studies in the country, and the proposed model can consider for future national and international studies. The model will provide the necessary conjuncture of most select variables that predict the adoption of CLE systems and maybe the starting point for other investigations that allow strengthening the results in other areas. The results achieved through this research can be an essential source of information for universities that intend to deploy collaborative tools, or that are at the beginning of this process. The information obtained can be managed to strengthen those variables that benefit the adoption of technology, to reduce acceptance times and minimize the risks of implementation due to lack of use by users.

\section{State of the Art}

The Information Systems (IS) have existed for some time in the investigations of computer science. However, Information and Communication Technologies (ICT) are comparatively new and innovative in many cases. [5], consider the degree of impact that ICTs have on people, organizations, and society. The presence of ICT is setting new educational scenarios, forcing higher education institutions to incorporate them into their teaching and learning processes. For tutorial, pedagogical, and communicative possibilities they offer to students [6].

Knowing the attitude of teachers towards a specific technology can be a handy tool when it comes to predicting the success or failure of the incorporation of a new information system (IS). Likewise, determining the key factors that affect the actual use of an IS by this group can serve as a guide to guide the integration process avoiding possible errors [7]. Innovation goes hand in hand with quality education, so it is essential to use principles that align the efforts of an educational system that will be privileged. For this we emphasize the following principles that go hand in hand with ICT: a) Dynamic learning, b) Collaborative learning, c) Autonomous teaching, d) Interactivity at various levels, e) Synchronous and asynchronous communication, f) Relevant and creative contents, and g) Continuous evaluation [8]. Within the process of technological integration, we can discover three key actors whose collaboration is essential for this to establish successfully: students, public administrations, and teachers [9]. Today, the use of ICT tools such as laptops, electronic pads, smartphone, along with the broadband Internet, interactive Web 2.0 technologies and cloud computing applications, 
have improved both teachings and learning in educational institutions [10].

Thanks to the rapid development of ICT, webbased LMS systems reached companies, which made it possible to access web-based content (support e-learning 1.0). These systems were followed by new LMS systems that support active learning (e-learning 2.0), based on the web of reading and writing. They opened new possibilities, such as chat, forum, wiki, e-portfolio, and workgroup [11]. Something exciting is the Sakai system's proposal with the Collaborative Learning Environment (CLE), which is a system developed in EBTIC according to [12], [6], which contains tools and functionalities that allow communication and collaborative creation of instruments within the same virtual environment.

The generation of knowledge and skills, the processing of information, and beliefs emphasize in cognitive theories [13]. It refers to the fact that cognitive theories emphasize the role of students' thoughts, beliefs, attitudes, and values. Although this research will not address cognitive approaches in-depth, a basic understanding is necessary.

Computer-based ICTs are essential for teaching and learning processes in fully online and mixed learning environments. The realization of classes in a purely online learning environment occurs in virtual learning spaces. In a diverse learning environment, traditional courses enhance with viable online learning resources. A more common functional description of a Learning Management System (LMS) is the primary use for online or blended learning. The functions of these systems include supporting the distribution of online course materials, associating students with courses, monitoring student performance, scoring student work, and mediating student-teacher communication systemically [14], [3].\&

Therefore, the LMS is a system through which the teaching-learning processes can manage through the systematic use of their Web 2.0 and Web 3.0 tools, either for virtual or online training and also as an instrument of support for traditional teaching, where the student is the interpreter of the learning process [15]. It must take into account that a virtual learning environment is related to interactive design, that certifies its use. In such a way that the creation of content and learning activities carried out in a productive and personalized approach, it proposes a type of evaluation that students must perform [16].

\section{Methodology}

The type of sampling is the stratified probabilistic; it will apply to a population of 157 students of the different academic cycles. From these data, we proceed to calculate the sample through a statistical formula using which is detailed below; this will allow knowing the number of students to apply the survey.

Now it is necessary to define the proposed new model, which uses TAM as a base model, which also includes variables or factors focused on Collaborative Learning Support Systems aimed at university students. As well as adding variables already considered in the known extensions of TAM, as well as TAM2, TAM3, and UTAUT. In this doctoral work, it proposes that PU (Perceived Utility), PEOU (Perceived ease of use) influence BI (Intention of Use), and this last factor determines the AU (Use of the System). For the model construction, other existing solutions studied and analyzed, extracting some factors and variables that were considered essential for the context in which the proposed model focuses. The systematic review of the TAM model literature and its variants made it possible to verify the explanatory capacity of the initial study by Davis (1989b) since significant relationships found between PU, PEOU, AU, and BI in the use of elearning. The external variables systematically reviewed that adapt to predict the Collaborative Learning Environment (CLE) system with the Sakai software, aimed at students, to use in this new model are as shown in figure 1 in a schematic way:

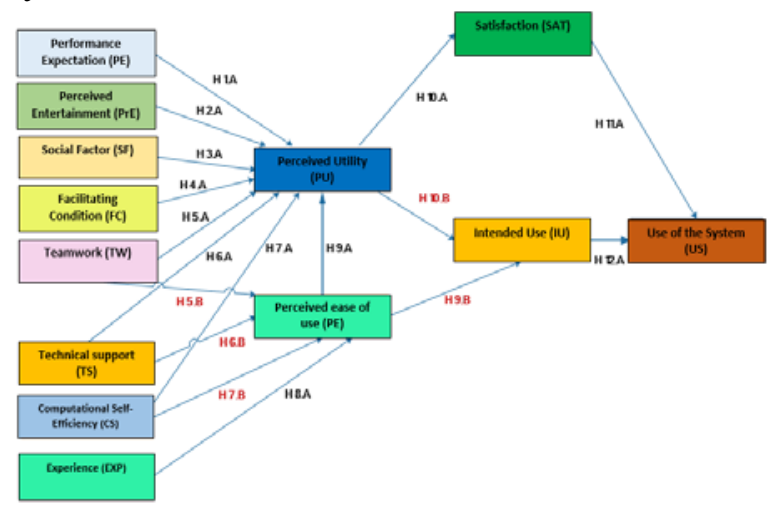

Fig. 1 The proposed theoretical model of technology adoption (CMAT).

An instrument was applied to validate the proposed model: to measure the service received quality, 
measure the use and acceptance of Information Technologies concerning the Sakai system. The instrument was applied to students of the Technical University of Cotopaxi since it was considered to apply the instrument to a heterogeneous population to guarantee results as close to reality, as shown in the following table. A model of structural linear equations is applied to know the relationships between the variables and also the predictive domain of the structural model to be used.

Table 1

\section{DEMOGRAPHIC OF UNIVERSITY STUDENTS}

\begin{tabular}{|c|c|c|}
\hline $\begin{array}{l}\text { Student } \\
\text { information }\end{array}$ & & $\begin{array}{l}\text { Frequency } \\
\text { (\%) }\end{array}$ \\
\hline Gender & $\begin{array}{l}\text { Male } \\
\text { Female }\end{array}$ & $\begin{array}{c}107(68.2 \%) \\
50(31.8 \%)\end{array}$ \\
\hline Age & $\begin{array}{c}\text { Under } 20 \text { years } \\
\text { Between } 20 \text { - } \\
25 \text { years } \\
\text { Between } 26 \text { - } \\
30 \text { years } \\
\text { Greater than } 30 \\
\text { years }\end{array}$ & $\begin{array}{c}39(24.8 \%) \\
102(65 \%) \\
15(9.6 \%) \\
1(0.6 \%)\end{array}$ \\
\hline Faculty & $\begin{array}{c}\text { CAREN } \\
\text { CIYA } \\
\text { CCAA } \\
\text { CCHH } \\
\text { CCFF } \\
\text { Language }\end{array}$ & $\begin{array}{c}30(19.1 \%) \\
30(19.1 \%) \\
30(19.1 \%) \\
30(19.1 \%) \\
7(4.5 \%) \\
30(19.1 \%)\end{array}$ \\
\hline $\begin{array}{l}\text { Study time at } \\
\text { the university }\end{array}$ & $\begin{array}{l}\text { Less than } 1 \\
\text { year } \\
\text { From } 1 \text { to } 3 \\
\text { years } \\
3 \text { to } 5 \text { years } \\
\text { More than } 5 \\
\text { years }\end{array}$ & $\begin{array}{c}4(2.5 \%) \\
128(81.5 \%) \\
24(15.3 \%) \\
1(0.6 \%)\end{array}$ \\
\hline $\begin{array}{l}\text { Time of hours } \\
\text { on the daily } \\
\text { Internet }\end{array}$ & $\begin{array}{l}\text { Less than } 1 \\
\text { hour } \\
\text { From } 1 \text { to } 3 \\
\text { hours } \\
3 \text { to } 5 \text { hours } \\
\text { More than } 5 \\
\text { hours }\end{array}$ & $\begin{array}{c}4(2.5 \%) \\
55(35.0 \%) \\
57(36.3 \%) \\
41(26.1 \%)\end{array}$ \\
\hline
\end{tabular}

The PLS technique (Partial Least Squares) was used to address the research question (Chin et al., 2003; Garson, 2016). PLS is an adequate technique for its ability to work with reduced sample sizes, which occurs when performing an analysis of this type. Measurement models were analyzed with SmartPLS 3.0 software (Ringle, Wende, and Will, 2017).

PLS is an SEM technique based on variance; it is widely used in administrative sciences, computer science, and health sciences. Its ability to model indicators and constructs makes it a good option for statistical tools for the investigation of new information and communication technologies (Henseler, Hubona \& Ray, 2016)

In the structural equation models (SEM), as is the case of the PLS analysis, to test the hypotheses, two steps are followed: first, the reliability and validity of the measurement scales are assured, to later approach the structural model itself and propose an improved model. Subsequently, the model predictive validity was evaluated.

\section{Overall assessment of the model}

In the evaluation of the teacher model's overall adjustment, the SRMR is not less than 0.08. The SmartPLS program shows us several indexes, and they are presented in the Table.

Table 2

OVERALL ADJUSTMENT INDEX OF THE PROPOSED MODEL

\begin{tabular}{|c|c|c|}
\hline $\begin{array}{l}\text { Adjustment } \\
\text { measure }\end{array}$ & $\begin{array}{l}\text { Adjustment } \\
\text { measure }\end{array}$ & $\begin{array}{l}\text { Adjustment } \\
\text { measure }\end{array}$ \\
\hline SRMR & 0.091 & 0.101 \\
\hline d_ULS & 6.390 & 7.909 \\
\hline rms Theta & 0.160 & \\
\hline
\end{tabular}

The saturated model is the least restrictive model in which all structural relationships are allowed (that is, all the route coefficients are free parameters). The model of independence or null model is the most restrictive model without relations between the latent variables (that is, all the route coefficients are required to be 0 ). 


\section{Reliability and validity of the}

\section{measurement model}

One of the most commonly used tests or measures to calculate reliability is the Cronbach's Alpha coefficient, in which case the reliability values must be $\geq 0.70$ to be accepted. The Cronbach's Alpha was calculated in each of them to verify the reliability with loads over 0.707 . For the interpretation of the results, we have to take into account that the correlations between 0.8 and 1 are considered very high. The reliability and validity of the instruments were carried out through the Cronbach's alpha test and the Spearman coefficient analysis, where Charles Edward Spearman, who developed the ordinal correlation coefficient that bears his name, which allows correlating two variables by ranks, instead of measuring the separate performance in each of them.

This coefficient is very useful when the number of pairs of subjects (n) that one wishes to associate is small (less than 30). Apart from allowing knowing the degree of association between both variables, with Spearman's Rho, it is possible to determine the dependence or independence of two random, 157 questionnaires were applied in the faculties of Agricultural Sciences and Natural Resources (CAREN, acronym in Spanish) with 30 surveys, Sciences of Engineering and Applied (CIYA, acronym in Spanish) with 30 surveys, Administrative Sciences (CCAA, acronym in Spanish) with 30 surveys, Humanistic Sciences (CCHH, acronym in Spanish) with 30 surveys, Center of Physical Culture (CCFF) with 7 surveys and Languages with 30 surveys.

The instrument to validate the service quality, measure the Use and acceptance of Information and Communication Technologies, consists of 13 variable questions: Performance expectation (3 questions), Perceived entertainment (3 questions), Social factor (3) questions), Facilitation condition (3 questions), Teamwork (3 questions), Technical support (3 questions), Computational self-efficacy (3 questions), Experience (3 questions), Satisfaction (3 questions), Perceived utility (3 questions) ), Perceived Use Facility (3 questions), Intent to use (3 questions), Use of the system (3 questions).

\section{Table 3}

RELIABILITY AND VALIDITY OF THE PROPOSED MODEL

\begin{tabular}{|l|c|c|}
\hline Constructions & $\begin{array}{c}\text { Cronbach's } \\
\text { alpha }(\alpha)\end{array}$ & $\begin{array}{c}\text { Spearman } \\
\text { correlations } \\
\rho(\text { rho })\end{array}$ \\
\hline $\begin{array}{l}\text { Performance } \\
\text { Expectation }\end{array}$ & 0.875 & 0.877 \\
\hline $\begin{array}{l}\text { Perceived } \\
\text { Entertainment }\end{array}$ & 0.821 & 0.828 \\
\hline Social Factor & 0.601 & 0.765 \\
\hline $\begin{array}{l}\text { Facilitating } \\
\text { Condition }\end{array}$ & 0.588 & 0.773 \\
\hline $\begin{array}{l}\text { Teamwork } \\
\text { Technical } \\
\text { support }\end{array}$ & 0.869 & 0.871 \\
\hline $\begin{array}{l}\text { Computational } \\
\text { Self- } \\
\text { Efficiency }\end{array}$ & 0.509 & 0.914 \\
\hline Experience & 0.388 & -0.013 \\
\hline Satisfaction & 0.866 & 0.870 \\
\hline $\begin{array}{l}\text { Perceived } \\
\text { Utility }\end{array}$ & 0.894 & 0.898 \\
\hline $\begin{array}{l}\text { Ease of } \\
\text { Perceived Use }\end{array}$ & 0.901 & 0.902 \\
\hline $\begin{array}{l}\text { Intention to } \\
\text { Use }\end{array}$ & 0.840 & 0.846 \\
\hline $\begin{array}{l}\text { Use of the } \\
\text { System }\end{array}$ & 0.884 & 0.925 \\
\hline
\end{tabular}

Hypothesis If Information and Communication Technologies are implemented, the level of satisfaction will be increased.

The approach of the Hypothesis:

$\mu 1=$ Average time of material development in the Pre-Test.

$\mu 2=$ Average time of material development in the Post-Test.
$\mathrm{H}_{0}: \mu_{1} \geq \mu_{2}$
$\mathrm{H}_{\mathrm{a}}: \boldsymbol{\mu}_{1}<\boldsymbol{\mu}_{2}$ 


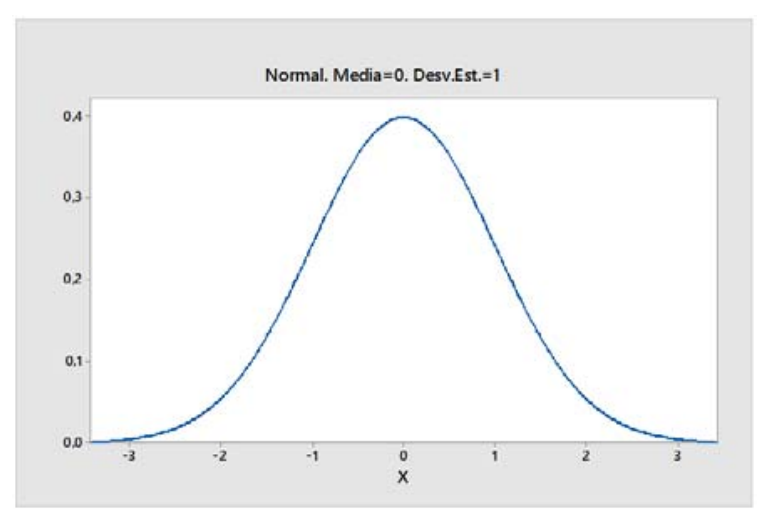

Fig. 2 Decision criteria

a) Calculation: Test $t$ for measurements of samples I6

Table 4

DESCRIPTIVE STATISTICS

\begin{tabular}{|c|c|c|c|c|}
\hline Sample & $N$ & $\begin{array}{c}\text { Me } \\
\text { dia }\end{array}$ & $\begin{array}{c}\text { Desv. } \\
\text { Est. }\end{array}$ & $\begin{array}{c}\text { Standard error } \\
\text { of the mean }\end{array}$ \\
\hline $\begin{array}{c}\text { PrePrueb } \\
\text { a_1_1_1_- } \\
1 \_1\end{array}$ & $\begin{array}{c}4.5 \\
0\end{array}$ & 2.42 & 0.44 \\
\hline $\begin{array}{c}\text { PostPrue } \\
\text { ba_1_1_1 } \\
\text { 1_1 }\end{array}$ & 3 & 26. & 2.34 & 0.43 \\
\hline
\end{tabular}

b) Estimation of the difference

\begin{tabular}{|l|c|}
\hline Difference & 95\% upper limit for the difference \\
\hline-21.633 & -20.607 \\
\hline
\end{tabular}

c) Test

\begin{tabular}{|c|c|c|}
\hline \multicolumn{2}{|c|}{ Null hypothesis } & $H_{o}: \mu_{1}-\mu_{2}=0$ \\
\hline \multicolumn{2}{|c|}{ Alternative hypothesis } & $\mathrm{H}_{1}: \mu_{1}-\mu_{2}<0$ \\
\hline Valor $T$ & $G L$ & Valor $p$ \\
\hline-35.25 & 57 & 0.000 \\
\hline
\end{tabular}

Decision: Since the p-value $=0.000<a=0.05$, the results provide enough evidence to reject the null hypothesis ( $\mathrm{H} 0)$, and the alternative hypothesis (Ha) is true. The test turned out to be significant.

\section{Conclusions}

This research paper presents a model of Adoption of Information and Communication Technologies, based on different models existing so far; it is desired to implement and improve the educational processes in students of the four faculties at the Technical University of Cotopaxi. The results obtained from the surveys made to the students of the faculties, allow the implementation of the Adoption Model of Information and Communication Technologies to improve the teaching-learning process in the students.

The model was validated using the statistical software Alfa de Cronbach, Correlations of Spearman, Minitab, each one of the indicators, was entered, and the comparison of them was applied, and it was demonstrated through the obtained results that the model implementation was a success. Currently, students' opinions about Web 2.0 technologies should be examined and addressed to reduce the negativity that can occur with the introduction of Web 3.0 technologies in the educational life of students and teachers. Therefore, concerns against Web 3.0 technologies can minimize risks and reduce technological integration problems if they are mitigated.The development of a proposal for a new model will depend on a series of critical factors, among others, problems and objectives of the research, analysis of gaps, target market (users or developers, etc.), objectives of the Higher education institution and understanding of existing models, the use of Web 2.0 tools makes the task more entertaining and helps to interact with contents in different formats. Care must be taken, however, because students are accustomed to working with these tools in their leisure activities and can spend time playing instead of working on learning activities. The research presented contributes to the development of learning using Web 2.0 and Web 3.0 and aims to improve education effectiveness by designing personalized activities and expanding the selection of ICT 
tools to support it in the educational process, a particular case of the Technical University of Cotopaxi. Finally, the systematic review of the literature was a fundamental contribution for the preparation of the papers on the Adoption Models of Information and Communication Technologies and Web 2 and Web 3, as well as the results obtained from the surveys made to the students of the Technical University of Cotopaxi that were the object of study.

\section{References}

[1] M. Zhou, L. Zhao, N. Kong, K. Campy, S. $\mathrm{Qu}$ and S. Wang, "Factors influencing behavior intentions to telehealth by Chinese elderly: An extended TAM model," International Journal of Medical Informatics, vol. 126, pp. 118-127, 2019.

[2] K. Manis and D. Choi, "The virtual reality hardware acceptance model (VR-HAM): Extending and individuating the technology acceptance model (TAM) for virtual reality hardware," Journal of Business Research, vol. 100, pp. 503-513, 2019.

[3] N. Chintalapati and V. Kumar, "Examining the use of YouTube as a Learning Resource in higher education: Scale development and validation of TAM model," Telematics and Informatics, vol. 34, pp. 853-860, 2017.

[4] M. Ramkumar, T. Schoenherr, S. Wagner and M. Jenamani, "Q-TAM: A Quality Technology Acceptance Model for Predicting Organizational Buyers' Continuance Intentions for E-Procurement Services," International Journal of Production Economics, vol. Acceptanced Manuscript, p. In Press, 2019.

[5] J. Sánchez, S. Olmos-Migueláñez and F. García-Peñalvo, "MLearning and pre-service teachers: An assessment of the behavioral intention using an expanded TAM model," Computers in Human Behavior, vol. 72, pp. 644-654, 2017.

[6] Muñoz-Leiva, F., S. Climent-Climent and F. Liébana-Cabanillas, "Determinants of intention to use the mobile banking apps: An extension of the classic TAM model," Spanish Journal of Marketing - ESIC, vol.
27, no. 1, pp. 25-38, 2017.

[7] J. Pando-Garcia, I. Perianñez-Cañadillas and J. Charterina, "Business simulation games with and without supervision: An analysis based on the TAM model," Journal of Business Research, vol. 69, no. 5, pp. 17311736, 2016.

[8] C. Yoon, "Extending the TAM for Green IT: A normative perspective," Computers in Human Behavior, vol. 83, pp. 129-139, 2018.

[9] R. Cakir and E. Solak, "Attitude of Turkish EFL Learners towards e-Learning through Tam Model," Procedia - Social and Behavioral Sciences, vol. 176, no. 20, pp. 596-601, 2015.

[10] B. Wu and X. Chen, "Continuance intention to use MOOCs: Integrating the technology acceptance model (TAM) and task technology fit (TTF) model," Computers in Human Behavior, vol. 67, pp. 221-232, 2017.

[11] B. Shafit-Zagardo, R. Gruber and J. DuBois, "The role of TAM family receptors and ligands in the nervous system: From development to pathobiology," Pharmacology \& Therapeutics, vol. 188, pp. 97-117, 2018.

[12] N. Jokar, S. Ali, M. Sadegh and C. Damalas, "Consumers' acceptance of medicinal herbs: An application of the technology acceptance model (TAM)," Journal of Ethnopharmacology, vol. 207, pp. 203-210, 2017.

[13] L. Wallace and S. Sheetz, "The adoption of software measures: A technology acceptance model (TAM) perspective," Information \& Management, vol. 51, no. 2, pp. 249-259, 2014

[14] M. Xia, Y. Zhang and C. Zhang, "A TAMbased approach to explore the effect of online experience on destination image: A smartphone user's perspective," Journal of Destination Marketing \& Management, vol. 8, pp. 259-270, 2018.

[15] R. Estriegana, J. Medina-Merodio and R. Barchino, "Student acceptance of virtual laboratory and practical work: An extension of the technology acceptance model," Computers \& Education, vol. 135, pp. 1-14, 
2019.

[16] M. Cheng and A. Kau, "Student continuance of learning management system use: A longitudinal exploration," Computers \& Education, vol. 120, pp. 241-253, 2018.

[17] Bhagwan Shree Ram, M. Selvaraj, Investigations on Barriers to the Incorporation of Information and Communications Technologies in Small Scale Industries, WSEAS Transactions on Information Science and Applications, pp. 242-250, Issue 8, Volume 9, August 2012

[18] Paul Nikolaidis, Dimitrios Xanthidis, ICT for the disabled: Policies and Issues, WSEAS Transactions on Information Science and Applications pp.359-367, Volume 12, 2015 